\title{
Fiscal Asymmetric Decentralization and the Influence of County Fiscal Autonomy on Household Effects in Kenya
}

\author{
Cyrus Mwangi Munyua ${ }^{a}$, Stephen Muchina ${ }^{b}$, Beatrice Ombaka ${ }^{c}$ \\ ${ }_{a, b, c}$ School of Business, Karatina University, Kenya \\ cmmunyua@gmail.com
}

\begin{abstract}
Fiscal asymmetric decentralization is seen as the panacea in solving persistent income inequalities facing developing economies. Despite efforts to finance County governments, about 42\% of Kenyan's 47.6 million people still live below the poverty level. This study evaluates the influence of County fiscal autonomy on household effects in Kenya. Both primary and secondary data, collected from households in 47 county governments and the Commission on Revenue Allocation, respectively. A Sample of 4,813 households was drawn from 96,251 lists of households developed by Kenya National Bureau of Statistics. Cochran's correction formula was used. The result finds an insignificant negative correlation between county fiscal autonomy and household effects in Kenya. Further studies are recommended with diverse indicators. Findings in this paper are generalizable and a point of reference for policymakers in Kenya.
\end{abstract}

Article Info

- Received : November 23, 2019

- Revised : December 15, 2019

- Published : January 18, 2020

- No. Pages : 80-87

- DOI : 10.33019/ijbe.v4i1.252

- JEL : E62, H31

- Keywords : fiscal, asymmetry, decentralization, IFMIS, reforms, PFM

\section{Introduction}

Fiscal autonomy has been viewed as an enabler in the course of long transformations in democratization process of the government and general local government autonomy for a long time. This is because the aspect of local government autonomy is considered a very important topic in public finance literature particularly in developing countries where majority of people live below poverty level, including Kenya. It has been found to positively impact on fiscal decentralization process by increasing market size and benefits of decentralized provision of public goods especially in Europe (Stegarescu, 2009). World Bank postulates that $95 \%$ of democracies have transferred their fiscal powers from central level to subnational governments. Developed countries that have transferred their fiscal powers include the United States, United Kingdom, and Canada (Xie, Zou, \& Davoodi, 1999). Other countries where fiscal decentralization initiatives are also taking place in developing nations are Mexico, Brazil, Bolivia, Belarus, South Africa, and Nigeria. World Bank has supported fiscal decentralization trend in developing countries on-premises that fiscal decentralization forms the main part of its poverty reduction programs (Martinez-Vazquez \& McNab, 2006). 
Several African countries have decentralized their provision of goods and services from the national level to devolved units. This includes Botswana, Burkina Faso, Ethiopia, Ghana, Mali, Mozambique, Nigeria, South Africa, Tanzania, Uganda and Kenya (Dickovick \& Riedl, 2010). The government of Kenya redefined her structure of governance from a unitary system to a devolved system in 2010 and entrenched it to the Constitution of Kenya 2010, which created 47 county governments and a national government (Hope 2014). From the onset of devolution in several fiscal reforms have been done towards the implementation of new Constitution including legislative amendments and repealing other Acts of Parliament. Reforms that have taken place in Kenya include the provision of public goods and services which is informed by Article 201 and regulated by the Public Finance Management Act 2012. The Acts also sets principles of management of public service and emphasizes them as a requirement in the budget formulation (Hope, 2014).

PFM Act 2012 also creates County Treasury and bestows them with the task of managing financial resources and in the creation of own revenue sources. Act postulate that borrowing and loan guarantees to County Governments must, however, be authorized by the National Assembly. It is within the Powers of County governments to execute its budget by appointing qualified and responsible chief officers who are the accounting officers to authorize all expenditures, write-off losses, make cash advances and manage assets and liabilities (Mitullah \& Nguri, 2012). Government of Kenya has been able to maintain a high level of investment through domestic financing, for example, the investment gap expanded from about $3.2 \%$ of GNP in $1965-69$ to $6 \%$ in the 1980 s. The country has come to rely increasingly on external resources to finance its capital formation due to the wide budget deficit caused by domestic financing. Overall budget deficit increased from 4.9\% of GDP in 1969-73 to $9.4 \%$ in $1979-83$ and was about $5.0 \%$ in 1989-990, resulting in a policy intervention (Cohen \& Hook, 1987).

An aspect of local government autonomy is considered a very aid in the fiscal decentralization process especially in the provision of public goods especially in Europe (Stegarescu, 2009). Government of Kenya has transferred KShs.1, 459.9 billion in 2012/2013 to Sh3 trillion (US $\$ 29$ billion) in this fiscal year 2019/2020 in an effort to create fiscal autonomy in county governments. Despite this effort, $42 \%$ of Kenya's population of 47.6 million people still lives below the poverty level of less than one (1) USD per day. Based on the above, this study undertook an investigation on the influence of County fiscal autonomy on household effects in order to answer the research question whether fiscal asymmetric decentralization influences household effects in Kenya.

\section{Literature Review}

Classical theory of fiscal federalism postulates that the transfer of fiscal powers to sub-Fiscal autonomy is a key concept in fiscal decentralization literature. Term fiscal autonomy refers to the freedom given to sub government levels to perform duties and competencies independently. True fiscal decentralization encompasses an expenditure generated from local authorities own sources of revenue. Secondly, the central government should allow subnational governments to have substantial control over their own revenues generated from set tax rates and/or determine the tax base in order to develop their own revenue-raising powers (Oates, 1956). Lu \& Sun (2013) assert that Local Government Authorities are considered independent when they finance their expenditure responsibilities mainly from their own revenues, such as local taxes, fees, and revenues from local property. This will make them enable them to make long-term financial planning and may improve local government accountability (Psycharis, Zoi, \& Iliopoulou, 2016). However fiscal autonomy might lead to a conflict of interest and hence compromise on the benefits of fiscal autonomy. 
Smoke (2017) postulate that the theory on fiscal federalism and facts on the ground are different. Ensuring that there is adequate subnational revenue is a core concern of fiscal decentralization. In this vein, Public finance principles for selecting and designing subnational revenue sources have been widely utilized during the prominent wave of decentralization efforts in developing countries over the past three decades. However, available empirical literature, suggests that subnational revenue generation often fails to meet needs and expectations, even where normative advice has been or seems to have been followed. Total expenditure includes all amounts of money that are paid out by a government during its fiscal year, normally twelve months, net of recoveries and other correcting transactions other than for retirement of debt, purchase of investment securities, extension of loans, and agency or private trust transactions (Ball \& King, 2006). Argument in favour of fiscal autonomy especially concerning revenue generation through external borrowing at local level is not without a pinch of salt, considering the debt crisis of subnational governments in Brazil, the inflationary impact of subnational financing in Argentina, and the city-level bankruptcies in the United States. Above anecdotes caused policymakers to rethink the extent of fiscal autonomy due to the possible macroeconomic implications of decentralizing borrowing powers. It is argued that problems such as the moral hazard may create unplanned fiscal liabilities for central government (Slack, 2017).

This paper is motivated by recent audit reports which indicate that there are numerous instances of fraud, wastage and poor accountability in County governments since the inception of devolution in Kenya. This is against the backdrop of information that the national government has greatly increased funding in the county governments including an equalization fund pegged at $15 \%$ of the national revenue. Amazingly, there have also been cases of money budgeted for development projects being returned to the National treasury at the end of the fiscal year. Further, uncertainty exists on the negative correlation between the total development budget that is disbursed and is spent and the level of development, poverty prevalence or access to essential services (Kruk et al., 2017). Tokuoka \& White (2017) define a household as a unit consisting of one or more people who live in the same dwelling and also share meals or living accommodation. This may consist of a single-family or some other grouping of people.

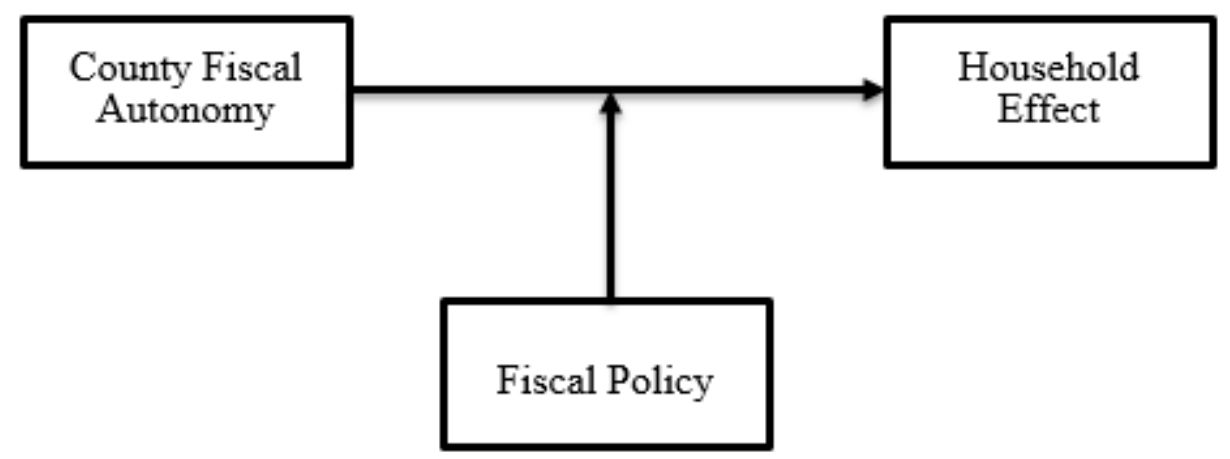

Figure 1. Conceptual Framework

\section{Research Methods}

Population in this paper consists of households domiciled in 47 county governments in Kenya. A Sample of 4,813 households was drawn from the 96,251 lists of households used by the Kenya National Bureau of Statistics in the 2009 enumeration areas by use of the Cochran's (1977) correction formula. Study made use of both primary and secondary data. Primary data was collected through the use of a household interview schedule while County fiscal data was 
sources from the Commission of Revenue Allocation and the National Treasury. Ordinary Least Squares (OLS) regression model was used to establish the association between the independent and dependent variables. Regression analysis was done using STATA (version 14) software. The regression model used is as follows:

$$
\begin{aligned}
& Y=\beta_{0}+\beta_{1} X_{1}+\varepsilon \\
& Y=\beta_{0}+\beta_{1} X_{1}+\varepsilon
\end{aligned}
$$

Where:

$\mathrm{Y}=$ Dependent variable (Household effects)

$\mathrm{X}_{1}=$ County Fiscal Autonomy

$B_{i}$ is parameters and $\Sigma$ is the error term

$P$-value at $95 \%$ confidence level was used to determine the statistical significance of the constant terms coefficient terms $\beta_{1}$. The coefficient of determination $\mathrm{R}^{2}$ was used to determine how much variation in the dependent variables as is explained by the independent variables. Data were presented using tables and graphs where applicable for clarity and ease of understandability. Hypothesis to test whether fiscal autonomy has any influence on Household Effects was as follow:

Ho: $\beta 1=0$ (There is no correlation between County Fiscal Autonomy and household effects). H1: $\beta 1 \neq 0$ (There is a correlation between County Fiscal Autonomy and household effects).

\section{Results}

Study collected both primary and secondary data sets. Secondary data related to the 47 County governments. Fiscal data ranging between 2012/ 2013 and 2017/ 2018 fiscal Years was sourced from the Commission on Revenue Allocation and the National Treasury. Primary data was collected through a household survey by use of interview schedules. Household survey was adopted and conducted based on a population of 96,251 households drawn from the enumeration areas (EAs) prescribed by NASSEP V methodology as applied in Kenya Household Survey of 2013 by Kenya National Bureau of Statistics (KNBS). A sample size of 4813 households was selected by use of Cochran's (1977) correction formula, of these households, 2480 were successfully interviewed, yielding to an overall household response rate of 51 percent. Deviation was primarily due to the new structures occupied by the time of survey that was not initially occupied in the first visit in urban areas, while the gated community-style of residence proved difficult to access in some urban areas like in the City's upper market villas. Young families were seldom absent. In the rural areas, the terrain like in Muranga and some parts of Meru County were also difficult to access, while the researcher faced security concerns in some parts of the country, hence limiting the responses from the initial target group. According to Saunders, Lewis \& Thornhill (2007), a 30 to $40 \%$ response is considered as adequate in a survey, while Sekaran (2003) postulate 30\%. Hager, Wilson, Pollack \& Rooney (2003) however recommend 50\%. Based on these arguments, the response rate of $51 \%$ achieved in this study is therefore considered adequate.

\section{Demographic Characteristics of households}

Study sought to understand the respondents and representativeness of the sample. This was done by posing questions on some information relating to the respondent's gender, age, marital status, and the level of education of the household heads. This study is of the view that demographic characteristics of household are important in order to obtain a more complete representation of the social embeddedness of an individual, hence it is necessary to add further household characteristics like the household's education level, age and the household's head marital status. Other studies have shown that income differs depending on a person's age and 
gender. The studies have also established that income varies between men and women and during the life cycle. It is therefore imperative to consider the effects of demographic characteristics such as age and gender when seeking an explanation into the causes of household income inequalities (Etingoff, 2016). The findings on the characteristic of the sample are presented in Table 1.

First question was on the gender of the household head. Demographic characteristics include gender, generation, race and ethnicity, education, geographic region, and marital status of the respondents. Results in Table 1, reveal that $69.6 \%$ of the household heads were men while $30.4 \%$ were women. This implies that majority of the households are headed by men.

Table 1. Demographic Characteristics of Households

\begin{tabular}{ccccccc}
\hline Gender of Household Heads & N & Min. & Max. & Mean & Std.Dev & Percent \\
\hline Male & 1726 & - & - & - & - & 70 \\
\hline Female & 254 & - & - & - & - & 30 \\
\hline $\begin{array}{c}\text { Education level } \\
\text { Primary }\end{array}$ & 670 & - & - & - & - & 27 \\
\hline Secondary & 1280 & - & - & - & - & 51.6 \\
\hline Bachelors & 248 & - & - & - & - & 10 \\
\hline Post graduate & 282 & - & - & - & - & 11.4 \\
\hline Age & - & 20 & 76 & 42.55 & & \\
\hline
\end{tabular}

Source: Data analysis

Results in Table 1 indicate that 70 percent of the respondents were male while 25 percent were female. 5 percent did not respond to the researcher's interview schedule. This study abides with the United Nation (UN) 2013 policy document, which emphasizes gender sensitivity on all household survey. This study, therefore, meets the standard set by the UN Inter-Agency and Expert Group on Gender Statistics (IAEG-GS) and Kenya's vision 2030 which also emphasize on mainstreaming gender sensitivity in all government programs (Un \& Sahin, 2012).

\section{Effect of County fiscal Autonomy on Household Effect (Household Income)}

Study sought to establish the causation that exists between fiscal autonomy and household effects using household income indicator. To this end, the study runs an OLS regression model whose result is presented in Table 2 and 3 respectively.

Table 2. Regression Model: County Fiscal Autonomy and Household Income outcome

\begin{tabular}{l|c|c|c|c}
\hline & Coef. & Std. Err. & $\mathrm{t}$ & $\mathrm{P}>|\mathrm{t}|$ \\
\hline County fiscal autonomy & -0.30043 & 0.619993 & -0.48 & 0.629 \\
\hline cons & 1.659817 & 0.488625 & 3.4 & 0.001 \\
\hline R square & 0.0017 & & & \\
\hline Adj. R square & -0.0055 & & & \\
\hline F $(1,139)$ & 0.23 & & & \\
\hline Prob.>F & .6287 & & & \\
\hline
\end{tabular}

Skewness $/$ Kurtosis test Chi2 $=55.90$, Prob $>$ chi $2=0.000$

Breusch-Pagan test $\quad$ Chi2 $=0.25$, Prob $>$ chi2 $=0.6182$

Wooldridge test $\mathrm{F}(1,46)=0.177$, Prob $>F=0.6758$

Source: STATA output 
Results indicate that there is no significant relationship between county fiscal autonomy and household effects. This is indicated by a p-value of 0.6287 at $5 \%$ level of significance. Results imply that fiscal county dependence does not have a significant effect on household income. Skewness/Kurtosis test indicates that the data was not normally distributed since the probability value is less than 0.05 . However, normality was assumed since the number of observations was large. Breusch-Pagan test reported a p-value of 0.6182 , which is greater than 0.05 and hence the data was homoscedastic. Further, Wooldridge test reported a p-value of 0.6758 , which is greater than 0.05 and therefore, there was no autocorrelation. Study found that there is a weak negative relationship between county fiscal autonomy and household effects. This is supported by a correlation coefficient of -0.0307 . However, the association between the two variables is insignificant at 5\% level of significance. Findings imply that a change in county fiscal autonomy would negatively change household effects, though to a small extent.

Further, the findings reveal that there is a weak negative relationship between county fiscal autonomy and household health. This is supported by a correlation coefficient of -0.0307 . However, the association between the two variables is insignificant at $5 \%$ level of significance. Findings imply that a change in county fiscal autonomy would negatively change household health, though to a small extent. This result agrees with Bergh and Henrekson (2011) findings that a negative relationship between public actual expenditure and household income inequalities exist in OECD countries. Likewise, a recent study by Fall and Fournier (2015), confirms that a negative relationship between the size of government and GDP growth also exist.

\section{Effect of County Fiscal Autonomy on Household Effect (Household Income)}

Further, Table 3 indicates the result of the relationship between county fiscal autonomy and household health outcome.

Table 3. Household Effects and Household Health Indicator

\begin{tabular}{lcccc}
\hline & Coef. & Std. Err. & t & P>|t| \\
\hline County fiscal autonomy & -0.34374 & 0.949112 & -0.36 & 0.718 \\
\hline cons & 2.372078 & 0.748009 & 3.17 & 0.002 \\
\hline R squared & 0.0009 & & & \\
\hline Adj. R squared & -0.0062 & & & \\
\hline F $(1,139)$ & 0.13 & & & \\
\hline Prob.>F & 0.7178 & & & \\
\hline
\end{tabular}

Source: STATA output

Study finds that there is no significant relationship between county fiscal autonomy and household effects when household health is used as an indicator. This is indicated by a p-value of 0.718 at $5 \%$ level of significance. This implies that county fiscal autonomy does not have a significant effect on household health. One of the setbacks on the gains of fiscal autonomy in Nigeria is the incursion of the military in Nigerian government and politics. This has resulted to a contraction in fiscal space from the regional governments to the central government resulting to substantially reduced power and independence of the federating units which is inimical to the goal of nation-building in plural Nigeria (Ejikeme, 2012).

In Kenya, it has been found that county government's Own-source revenue contributed 13 percent of the total County Governments receipts in the first three years of devolution, while transfers from the National Government accounted for more than 84 percent. On the other hand, 
economic growth in the same governments dropped from 18.8 percent between FY 2013/14 and 2014/15 to 3.1 percent between FY 2014/15 and 2015/16. This casts aspersions on the success of fiscal autonomy in meeting its goal in tandem with the theory of fiscal federalism's viewpoint in improving the welfare of local citizens and the resource dependence theory (Oak, 1956).

\section{Conclusion and Recommendation}

This study provides new evidence on county fiscal autonomy on own revenue source and household income as indicators of the relation between fiscal asymmetric decentralization and household effects. This study has analyzed the dichotomy in financing devolved government services. But the study has also found other literature that supports the fact that decentralization ought to be carried out in a continuum. However, where there exist several political parties in a coalition, pressure to devolve functions also exist which disrupt the prior arranged modus operadi of devolution of government functions, resulting in a dichotomous nature. Kenya is not left out on this. During the study period, there have been numerous reports of misappropriation of government's funds at County levels on one hand, while Kenya has also reduced in the World ranking on corruption perception index. This study, therefore, concludes that though there has been increased county funding by the national government in Kenya, it is possible that the same has not been utilized for the intended purpose. The government should, therefore, enhance monitoring and evaluation of County governments and introduce other methods of budget implementation and oversight.

\section{References}

1) Ball, R. \& King, D. (2006). The private finance initiative in local government. Economic Affairs, 26(1), pp.36-40.

2) Cohen, J. M. \& Hook, R. M. (1987). Decentralized planning in Kenya. Public Administration and Development, 7(1), pp.77-93.

3) Dickovick, J. T. \& Riedl, R.B. (2010). Comparative assessment of decentralization in Africa: final report and summary of findings. Washington, DC: United States Agency for International Development (USAID).

4) Etingoff, K. ed. (2016). Ecological resilience: Response to climate change and natural disasters. CRC Press.

5) Kruk, M. E., Chukwuma, A., Mbaruku, G., \& Leslie, H. H. (2017). Variation in quality of primary care services in Kenya, Malawi, Namibia, Rwanda, Senegal, Uganda and the United Republic of Tanzania. Bulletin of the World Health Organization, 95(6), p.408.

6) Lu, Y. \& Sun, T. (2013). Local government financing platforms in China: A fortune or misfortune? (No. 13-243). International Monetary Fund.

7) Martinez-Vazquez, J. \& McNab, R.M. (2006). Fiscal decentralization, macro stability, and growth.

8) Mitullah, W. V. \& Nguri, J. (2012). Intergovernmental Relations Act 2012: Reflection and Proposals on Principles, Opportunities and Gaps.

9) Nudzor, H. P. (2014). An analytical review of education policy-making and implementation processes within the context of "decentralized system of administration" in Ghana. Sage Open, 4(2), p.2158244014530885.

10) Oates, W. E. (1994). Federalism and government finance. Modern public finance, 126(1999), pp.1120-1149. 
11) Psycharis, Y., Zoi, M., \& Iliopoulou, S. (2016). Decentralization and local government fiscal autonomy: evidence from the Greek municipalities. Environment and Planning $C$ : Government and Policy, 34(2), pp.262-280.

12) Sahin, S. B., Lewis, B., \& Lewis, J. (2012). Fractured futures: Indonesian political reform and West Timorese manganese mining. Global Change, Peace \& Security, 24(2), pp.289304.

13) Saunders, M., Lewis, P., \& Thornhill, A. (2007). Research methods for business. London: Pitman, pp.124-126.

14) Slack, E., 2017. How Much Local Fiscal Autonomy Do Cities Have? A Comparison of Eight Cities around the World. Institute on Municipal Finance and Governance.

15) Smoke, P. (2017). Looking beyond conventional intergovernmental fiscal frameworks: principles, realities, and neglected issues. Central and Local Government Relations in Asia, p.64.

16) Stegarescu, D. (2009). The effects of economic and political integration on fiscal decentralization: evidence from OECD countries. Canadian Journal of Economics/Revue Canadienne d'économique, 42(2), pp.694-718.

17) Xie, D., Zou, H. F., \& Davoodi, H. (1999). Fiscal decentralization and economic growth in the United States. Journal of Urban Economics, 45(2), pp.228-239.

18) Psycharis, Y., Zoi, M., \& Iliopoulou, S. (2016). Decentralization and local government fiscal autonomy: evidence from the Greek municipalities. Environment and Planning C: Government and Policy, 34(2), 262-280. 